\title{
Constance Maynard's Life-Writing Considered as Spiritual Autobiography
}

Elisabeth Jay, Oxford Brookes University

Abstract:

Viewing Constance Maynard's unwieldy life-writings within the tradition of spiritual autobiography reveals many of the irresolvable tensions with which she wrestled. Although she chose to see her public role as spearheading a crusade against modern rationalism, her inner life was as much concerned with the struggle to repudiate her parents' ascetic Evangelical piety in favour of a more emotionally intense spirituality. Her conviction of conversion's centrality fostered a sense of mission which bolstered a sense of her own exceptionality as a 'prophet' chosen by God. This in turn nourished her belief that she was justified in exempting herself from the roles and relationships conventionally assigned to her gender, by pursuing same-sex desire and sexless motherhood.

Biography:

Elisabeth Jay has published widely on fiction, prose and poetry of the nineteenth and early twentieth centuries, as well as on religion. She co-edited the Oxford Handbook of English Literature and Theology. She is also joint general editor of a 25 volume Pickering \& Chatto series of Oliphant's works. She has taught in Northern Ireland, France, Belgium and the USA as well as in Oxford. She has recently completed a study of 'British Writers and Paris in the Mid-nineteenth Century'. She is on the Advisory Boards of Literature \& Theology (OUP); English (OUP); Studies in Browning and His Circle; E-Rea Review (University of Aix en Provence, research laboratory journal) and Miranda (University of Toulouse Le Mirail, research laboratory journal). Correspondence to: Elisabeth Jay, 31 Stratfield Road, Summertown, Oxford, OX2 7BG, UK

Email: ejjay@brookes.ac.uk 


\section{Constance Maynard's Life-Writing Considered as Spiritual Autobiography}

Constance Louisa Maynard, (1849-1935), who as first mistress, led Westfield from its inception as a private tutorial college engaged in preparing students for London University degrees, to the position of a fully-incorporated constituent part of the university, is usually celebrated as a pioneer of women's higher education, and her extensive archive mined for the purposes of historical research into this phenomenon. ${ }^{1}$ Recent scholarship in educational history has often approached the autobiographical documents of the leading women educational campaigners of the latter half of the nineteenth century from the perspective of feminist or gender studies. ${ }^{2}$ In as much as Maynard's same-sex desire inflected both her spiritual life and her writing, these approaches remain pertinent to an article proposing to consider Maynard's archive as a type of life-writing best described as spiritual autobiography. Writing pertaining to the metaphysical side of life is nevertheless also marked by the bodily materiality of gendered desire. Indeed, in explaining the concept of 'embedded theology', Margaret Miles notes how medieval devotional manuals can often yield information on the ways that the faithful have instantiated their spiritual ideals in their daily lives, as they sought to translate Christianity's principles into quotidian bodily concerns and relationships. ${ }^{3}$ As Miles's emphasis upon the quotidian nature of piety also suggests, it will be important to situate Maynard's outpourings in a precise historical context, in terms of spiritual autobiography as a literary tradition, the changing complexities of nineteenth-century Evangelicalism, and the tensions caused as Maynard emerged from the old-fashioned and claustrophobic confines of her parents' religious practices, to encounter different understandings of Christian mission.

Historically-speaking, Maynard's is a late flowering of an Evangelical autobiographical tradition which might be said to have reached its high watermark by the end of the eighteenth century in the writings of religious leaders such as John Wesley or Thomas Scott who used 
their own life-stories to demonstrate the ways of God to man. ${ }^{4}$ Evangelicalism's stress on an unmediated, highly personal, relationship with God, justified an interest in the self which was particularly helpful in freeing women from the accusation of unbecoming self-importance in writing of their own experiences. Yet by the time Maynard adopted the form, the greatest examples of the genre spoke of an already remote, pre-industrial society, while her writings took place against an intellectual background where new discourses such as psychoanalysis were impinging on the concepts of self-consciousness and self-knowledge. As Maynard attempted to justify her escape from the conservative religious piety of her parental home, so she was forced into refashioning her understanding of her religious calling - a task which consumed reams of paper and could never, logically, see completion as long as God's overruling purpose for her life remained, as it often did, obscure.

Maynard's life-long habit of diary-keeping was both the making and undoing of her autobiography, and in order to understand the problems it created for her attempts at selfunderstanding, a brief account of the nature and inter-relation of the various writings in the Maynard archive is necessary. From their early years she and her five brothers and sisters had been taught to keep both a res gestae, logging weekly events and engagements, alongside a journal intime, tracing the incidents and influences which formed the inner life: in her own case she mentioned this dual practice as still operating in late $1918 .^{5}$

The first of the extant journaux intimes, or Green Books, named after the green morocco binding on the spine and corners of these volumes of ruled pages, dated from January 1866 when Maynard was $16 .^{6}$ This volume is more of a religious commonplace book, or scrapbook, regularly, but by no means daily, updated. It is used for inscribing texts, copying letters of advice she has received, and earnest correspondence with her older siblings, together with almost verbatim reconstructions of the sermons she has heard - a note-taking practice which 
would pay off handsomely when she attended lectures as a Girton student. There is the occasional reflection on the religious implications of public events, and some more personal meditations on her own spiritual state, recording examples of her Christian witness, usually followed by the fear that she has not been sufficiently faithfully outspoken.

It seems probable that Maynard began to keep both kinds of diary as early as 1861, the point at which the autobiography starts to offer a detailed commentary on her adolescent years. Her later claim that she had written nothing worth reading before 1866 suggests that she may have jettisoned earlier work. ${ }^{7}$

Maynard's inordinately lengthy, unpublished autobiography draws retrospectively on both these sources in her attempt both to record and interpret the events and emotions which had proved formative for her inner life and public achievements. To appreciate the competing influences at work in the composition of this sprawling, inchoate manuscript, it is appropriate first to consider the theological components which entered into Maynard's personal formation.

Maynard saw 1866, the year when she felt her writing had attained some significance, as a species of watershed. She had recently been withdrawn, after only a year, from Belstead school at age 16, on the grounds that her older sisters, who had remained until 18, were considered adequate to the task of transmitting their expensive experience to their younger sister. ${ }^{8}$ Maynard resented this, partly because she felt this had curtailed her formal education, but chiefly because Belstead had awakened her to a fresh perspective on the life at home she was now to resume. Indeed, the opening page of the 1866 Green Book reveals that she has been writing to Mrs. Umphelby, a much-valued teacher at Belstead, complaining that at home it was 'hardly noticed' whether she did right or wrong, a remark that initially seems all the more surprising in light of the cloistered piety in which the Maynard family lived. ${ }^{9}$ That sense of being 'noticed', for good or ill, would remain particularly strong in Constance, who had already 
realized that, as the youngest of four daughters who continued to be subject to their parents until such time as they married, it would be hard to make her individual mark.

More importantly for her future inner life, at Belstead Maynard had encountered a teacher whose way of practising Christianity seemed very different from the way it was observed at home, although both would now be broadly understood as coming under the capacious umbrella of 'Evangelicalism'. As Evangelicalism had spread and responded to a variety of other religious developments, so it had become more diverse: this was true even as regards to the understanding of the purposes of diary-keeping. The early Evangelicals had revived the Puritan use of a diary to record attempts to live up to the high demands of the ideal Christian life, but as some forms of Evangelicalism became inflected by different streams of pietistic practice, so the Puritan aid to reflection sometimes became the repository for a more inward-looking self-scrutiny. The differing emphases Maynard detected in her parents' and her teacher's understanding of Evangelicalism would lay the foundation both for much of Maynard's subsequent public career and for her inner turmoil. Crudely summarized, her teacher had introduced her to an Evangelicalism strong on the evidence of conversion and sense of mission, whereas her parents' interpretation stressed a constant battle with all forms of worldliness, and firmly resisted all hints of the emotional.

Theologically-speaking it is difficult to place Maynard's parents very precisely, but it is safe to say that the regimen they instilled was influenced as much by a Scottish Puritan mindset of the first half of the nineteenth-century as by mainstream Anglican Evangelicalism of the second half. Maynard came to regard the religion instilled by her parents, as abstract, devotionally impoverished, and more noteworthy for its sense of separation from the world 
than for its encouragement of a personal relationship with Christ, or any practical sense of evangelizing mission. Maynard's summary of their beliefs represents a curious mixture. The bedrock of their belief was the total depravity of mankind occasioned by the Fall, but they also emphasized the humanity of Christ. They believed in the verbal inspiration of the Bible in its original languages, but not in its various translations, thereby, as the daughter observed, allowing greater latitude to their own interpretations. They held the Visible Church and the Sacraments in low estimation, attending Communion only once a month; the heroes of their world included those unorthodox Scottish Presbyterians, Edward Irving and Campbell of Rowe, together with mystics such as Jacob Boehme, Madame Guyon and William Law. ${ }^{10}$ The eccentric nature of the Maynard brand of Evangelicalism is perhaps best caught in the family enterprise, for which Constance was co-opted as secretary, of countering the Ritualism of the early 1870s, by de-catholicising the Anglican Prayer-Book. ${ }^{11}$ Although the daughters, once grown-up, were sent to London for a spell each year to attend the Exeter Hall meetings of the large Evangelical missionary and philanthropic societies, and to take professional art instruction, Mrs Maynard seems to have preferred to continue her secluded life in their large house and garden in Kent, where, by her daughter's account, she operated as an amalgam of teacher, pastor, confessor, and Grand Inquisitor.

From the remarks attributed to 'Mother' in the 1866 Green Book, it is easy to see what Maynard meant by writing in her autobiography that her mother's teaching tended towards the 'abstract', consisting as it largely did of recommending Biblical texts offering general guidance. Looking back in 1916, and having read that 'heart-breaking book' Edmund Gosse's Father and Son (1907), Maynard recognized that her mother was not as intrusive as Gosse Senior: 'perhaps because her questions were less personal, they were hardly questions at all' ${ }^{12}$ 
Indeed, one of Maynard's implicit criticisms was that her mother applied a one-size-fits-all system to the very different characters of her children.

Maynard deduced that her oldest sister, Josephine, known as Tissy, and the youngest child, George, had managed, by an outward display of conformity, to remain immune to their mother's religious education. By 1916 Tissy had shown a youthful journal intime to Maynard who complained, that other than showing a gift for description, it revealed nothing of 'a very singular girl forced into an unsuitable mould, and wasting her remarkable powers' ${ }^{13}$ Possibly Tissy had learnt from watching her mother's approach to her brother, Harry, for whom maternal anxiety was all the greater because, as the oldest son, he was obliged to enter the family business and encounter daily temptations to 'wordliness'. In the year before his conversion, Harry's journal, Maynard wrote, showed on every page his 'heavings \& strugglings and endless self-condemnations', ${ }^{14}$ yet their mother persisted in using lengthy letters to preach separation from the things of this world to a son already in his mid-twenties.

Maynard's sympathy with Harry, arising from the fact that she too in subsequent life suffered from long bouts of doubt and religious depression, is revealed when she looked back on her own early Green Books, where she felt that her covert discontent emerged in her constant bewailing of her view that 'she is not good and must therefore pray more'. She came to see this attitude as the repression of a healthier self, as she later also deemed her attempts at concealing 'a private and ecstatic love for' her school friend, Fanny Williams 'which must be hidden from the authorities'. ${ }^{15}$ (It did not seem to occur to her that this attachment might have been an additional reason for removing her from school so swiftly: many years later she conjectured 
that her Mother had discouraged this friendship on account of Fanny's 'unbelieving, joking brothers'.) ${ }^{16}$

With the youngest child, George, next in age to Maynard, their mother's attempt at 'real conquest' did not 'take': Maynard simply observes that 'she did not pressure him with the relentless enquiries that she did Harry, hunting him down in every corner of his life', ${ }^{17}$ but perhaps we might infer a mother exhausted by a continuous regime of watchfulness, and content to believe in the transmission of the teaching already apparently imbued in her other children. Certainly by the time that Maynard, the penultimate child of a large brood, was preparing to leave home in her early twenties, she saw her mother as elderly and worn-out: 'By this time she paid no visits, went nowhere, \& I cannot but think her life, once so bright \& active, was getting very dull. ${ }^{, 18}$ Maynard's deep-seated ambivalence about her mother's failure to pursue George's religious welfare as intently as she had that of the others become apparent many years later in her Green Book for 1918. By then Harry was dying from cancer and apparently believed in 'nothing but the bitter, intolerable cold of interplanetary space', though Maynard remained sure that since she had been 'set apart as a prophet' it was her task to reach his inner 'true' self again. ${ }^{19}$ With George, however, she recognized that her task of imploring Christian forgiveness and reconciliation to the older brother who had, she agreed, treated George very badly in business terms, remained beyond the appeal to any residual, shared ethos from the children's upbringing.

Despite Maynard's many criticisms of the religious regime of her upbringing, it had been more influential than she perhaps recognized. Her parents' distrust of institutional Christianity emerges in her lamentations over the decline of the Girton prayer meetings she 
had initiated: they 'sank into coldness \&half-heartedness' and 'somewhere about 1895 ...the whole thing merged into the new organization of the "Student Christian Movement". Of this whole movement the G.P.M. of 1875 stood like a little Morning Star, that soon faded down' ${ }^{20}$ Maynard's subsequent prickly relations with those responsible for the continued viability of Westfield College would seem to reiterate this deep-seated fear that institutions are bound to betray the enthusiasm and commitment of their initiating spirits.

Whatever her mother's maternal failings, the leadership she exercised in matters of household worship, doubtless contributed to Maynard's sense of female potential. Although Maynard was slighting about the nature of the prayer meetings her mother organized in her room during the Franco-Prussian war -- 'It was not expansive, but there was strong reticence among us, \& it was better than nothing at all'21 --, the prominent part her mother played in guiding the family was by no means limited to the occasions when her husband was absent on lengthy business trips to South Africa. Maynard also retained more of her mother's spirit of condemning as 'worldliness' anything of which she instinctively disapproved, than she recognized. Inveighing in her autobiography about the way in which her mother protected her and her sisters in the 1860 s from any contact with 'the girl of the period' notions, and, to her daughters' chagrin, made sure they were always several years behind the fashion in their attire, Maynard recalled as one of her mother's typical remarks, when faced with a modishly-dressed young woman, 'a girl like that cannot be of any use in the kingdom of God!'.22 Yet, from the judgements Maynard continued to voice to her diary for the rest of her life, it is clear that she had internalized much, not only of her mother's way of thinking, but of its vocabulary. Reviewing a group of women she had encountered in her voluntary Christian work during the First World War, she considered that many of them were 'astray on the dark mountains': she told one, a Marion Wakefield, that she was 'on the down-grade' and 'swimming with the stream', whilst the Canadian Doris Jackson was simply written off as a 'poor spiritless fashion- 
plate' ${ }^{23}$ One of the most distasteful episodes, for today's sensibilities, is Maynard's decision to round off her account of her Girton days, by reviewing the subsequent careers of her contemporaries. Despite their many successes, as professional educators, in the communities where they lived, or in raising families, most are judged as 'worldly' in their aspirations, and as spiritual failures because they failed to carry forward Maynard's vision with the intensity she demanded: not one, she declared, was 'converted'. ${ }^{24}$

Although Maynard was to claim that her own religion as an adult was experiential and based upon the conviction of conversion, rather than on testimony as to the efficacy of the Cross, the tension between her earlier and later understanding of Evangelicalism was to be the source of unending problems in her personal spiritual life. ${ }^{25}$ There is of course nothing exceptional in the figure of a man or woman raised in an Evangelical family having continuing difficulty in identifying the point at which his or her personal conversion can identifiably and irrevocably be said to have taken place. Maynard's Green Books, and the episodes copied from them into her autobiography, continue throughout her life to show her praying for moments of revelation or absolute conviction: the final chapter of her autobiography, relating to the year 1927, still sees her seeking 'assurance' of her salvation. ${ }^{26}$ However, for Maynard, conversion was to become a new shibboleth, supplementing her mother's simpler division between the 'worldly' and 'unworldly', and thus enabling Maynard to class those who failed to embrace Christian mission in her own terms along with those who wholly rejected Christianity's claims. Despite her own periods of depression, she maintained a cast of mind which positioned her in a grand cosmic battle and thus allowed her to interpret resistance to her mission as the work of the enemy. 
In an early autobiographical chapter, which presumably drew on a discarded Green Book, she claims that as early as 1861-1862, when she was about twelve or thirteen, 'honestly I believe I was singled out for the lonely post of a prophet'. This was doubtless a comforting conviction for a young girl, suddenly bereft of her older sisters, who were away at school: their absence indeed may further have facilitated her desire to stake out a claim for her own significance. She further consoled herself that she was the same age as Jesus when he declared to his parents that he must be about His Father's business, and that even that eminent Evangelical, the great Lord Shaftesbury, sometimes felt lonely and mocked. As she wrote a couple of pages later, 'the objective of being somewhat of 'prophet' never wholly left me'. ${ }^{27}$ There is something of Charlotte Brontë's St. John Rivers's declaration, 'A missionary I resolved to be', ${ }^{28}$ in the slippage in Maynard's vocabulary between God-given vocation and career 'objective'. Nor does Maynard seem to have paused to interrogate the term 'prophet', using it mostly to suggest an Old Testament understanding of the especial role of God's direct spokesperson on earth, rather than a broader interpretation of the Christian imperative to evangelize.

The Old Testament role held out greater attractions in that it not only sanctioned the denunciation of those who failed to recognize her role and her teaching, but also enabled a powerful sense of personal revelation in which God communicated fresh understandings of His will directly to his chosen agent on earth. Lest this should seem at best a deliberately perverse, and at worst a cynical, reading of Maynard's writings, two further points need to be made, the first relating to spiritual autobiographies as a genre, and the second to Maynard's personal appropriation of the prophetic mode. 
The compelling conviction of a calling from God, sufficient to sustain them through opposition, calumny and periods of depression, is characteristic of the private writings of many of the great leaders of the Christian church. Given that Maynard saw her life as a crusade against the Zeitgeist of modern rationalism, fought out on the embattled field of higher education for women, she required as great a level of confidence in her own calling as a John Wesley or a John Henry Newman. The autobiographical writings of figures such as these often demonstrate a sense of their importance in God's designs, barely distinguishable, to the secular mind, from ill-disguised self-importance. A desire to pore over the minutiae of daily life, in order to discern God's governing hand at work, also tends to a loss of the teleological perspective modern readers have come to expect from the well-crafted autobiography.

In Maynard's case these generic factors created further problems. In her introduction to the autobiography she cites a two-fold purpose to the work: the desire to trace the history of higher education for women, and 'the far more compelling reason' of covering the whole period of 'the onslaughts of Criticism on Religion'. Recognising that the second aim was particularly 'intimately bound up with the individual life', she vowed to minimize the use of the personal pronoun, yet, since she drew so heavily on the Green Books which recorded 'everything that touched the inner life of the heart and the soul', this was a determination always unlikely to succeed. ${ }^{29}$ A new draft chapter, commenced in March 1927, began with the despairing resolution to start the enterprise again on a different scale because 'there are oceans of past writings, hundreds and hundreds of cramped little pages from which to draw my facts' ${ }^{30}$ Not only was the subjectivity of the Green Book always likely to prove at odds with the objectivity demanded by the public discourse she had at first intended, but the Green Books frequently employed a language derived from older religious traditions. Talking, for instance, of the flood of criticism with which religious belief had been bombarded in her lifetime, Maynard reverts 
to a trope which could well have come from John Bunyan's Grace Abounding to the Chief of Sinners (1666): 'It used to look to me like a long row of evil giants standing close beside the narrow path of life: one must go forward and escape was hopeless' ${ }^{31}$

While Bunyan's writings were still very familiar to most nineteenth-century readers, modern readers, more accustomed to the ironic tropes and poses favoured by post-modern selfrepresentation, are likely to perceive the earnest confessional religious writing of even a century ago, as a largely alien discourse. Coming to terms with the apparent unselfconsciousness involved in the alternating self-abasement and self-bolstering of Maynard's Green Books is further complicated for us by the fact that she had become familiar with some of the terminology of Freudian psychoanalysis. However, the insights she felt this afforded her into others' states of mind were rarely accompanied by any speculations as to the workings of her own unconscious. Writing in $1915 / 16$ in the autobiography, she mentioned having read her recent efforts at capturing her childhood years to the two sisters nearest in age to her, Gaby and Dora. Both of them declared hers to be too gloomy a picture. Maynard's reaction was to decide that Dora's personality probably inclined her to recollect the experience more positively, but of Gaby she concluded that she must have forgotten her own repressed rage: 'Her sense of duty must have been so strong, that the raging in secret found no expression at all, \&, as psychologists tell us, that is the surest way of smothering an emotion in oblivion.' Maynard's diagnosis is deduced from comparing the tale of happy activity told in Gaby's weekly diary, with 'the bitter sobs' and 'bitter laments' revealed in her sister's Green Books, without pausing to consider whether her own parallel records for this period might give rise to a similar finding. ${ }^{32}$ 
The second reason for subjecting Maynard's autobiography to the hermeneutics of suspicion arises from Maynard's personal interpretation of her role as God's prophet. Raised in a wealthy middle-class family who took the Art Journal and read Ruskin, despite his heretical views on total depravity, ${ }^{33}$ the girls were all encouraged to pursue art as a ladylike accomplishment, but Maynard swiftly persuaded herself not only that she was 'an artist manqué', ${ }^{34}$ but that with the right training she could have been 'a good artist', ${ }^{35}$ and this later turned into the view that she might have become an 'art critic'. ${ }^{36}$ Whatever the standard of her own artistic performances, the career of art critic was unlikely to have been open in the $1860 \mathrm{~s}$ and 1870 s to such an untravelled young woman. Her claims instead make it clear that Maynard was determined to be accounted exceptional in whatever sphere she chose. Girton provided this opportunity. Her sheltered home life had given her little contact with the wave of materialism which she perceived to be sweeping through the universities in the $1870 \mathrm{~s}$, but Girton gave her the platform from which to launch her personal mission. In aiming at breaking the link between Higher Education and secularism, Maynard had in effect set herself to reverse the mainstream tendency of late nineteenth-century intellectual life. This is by no means the first reading of Maynard as a woman strongly driven by self-belief. A fellow Girton student, the beautiful, non-church-attending, Rachel, bluntly put it to Maynard that perhaps she was imagining her belief and then acting upon it. ${ }^{37}$

Maynard was briefly unsettled by Rachel's attack which hit home because it came close to undermining her entire modus vivendi. Maynard had depended upon believing that her chosen methods of evangelism were wholly justified if they were subordinated to the imperative 'seek ye first the kingdom of God, and his righteousness'. Yet it is worth asking whether she had begun to rely equally heavily upon the promise in the second half of this text: 'and all these things shall be added unto you' ${ }^{38}$ To what extent did her strong conviction that 
it was her prophetic role to wage war on contemporary worldly norms allow her to envelop her sexual 'exceptionality' within the wider notion of being 'set apart' from society's normative behavioural modes? These may at first sight seem to be questions arising more from today's agendas, than those of Maynard's period, but the self-communings of her autobiography confront us with them very directly.

Rather than Maynard keeping what she refers to as her 'secret life' in a separate compartment from her religious vocation, her Green Books and autobiography make it clear that she sees them as integrally related. For example, looking back from 1927, to the year $1885 / 86$, which had been a 'breakpoint' in her life, she reminded herself of the inner desolation that year had brought. She congratulated herself on her own ability to put on a good public front, but admitted that the major portion of her years at Westfield had been made a 'cruel desert' largely by the course her lesbian romances had taken. 1885 had seen 'Ralph' [F.R Gray] supplant Margaret [M.G.Brooke] in Maynard's affections, but Ralph had responded by choosing to live out of College with her relatives rather than indulge Maynard's taste for intimate fireside sessions of an evening. Using her Green Book record to recreate the day on which Ralph left, Maynard moves within a sentence from idealizing Ralph as 'royally beautiful, with such a stainless honour of character', to identifying 'something inflexible, perhaps cruel, which could tear to pieces one so soft and slight as I.' Maynard's own fluctuating attachments and their sometimes disastrous consequences are forgotten, as she recasts her position as disappointed lover into the 'lonely post of prophet' she had marked out for herself since childhood. The way in which she effects this manoeuvre by having God legitimate their relationship, only to deprive her of it because it is proving detrimental to His greater cause, is particularly telling. 
It is as if the Lord said to me - 'There, I see it will not do. I would like to have trusted you with one of my very highest + best, but you are not strong enough. She has pulled you down to lean on one side, where I wanted you straight as a dart and this has subtracted your attention from the work as a whole + fixed it on the individual. I do not blame you too much. I am only sorry that it cannot be. You are not as upright + undivided as I had hoped. This arrangement may be better. ${ }^{39}$

The fact that in the eyes of liberal Christianity today Maynard would have had no need to justify her lesbianism, does not entirely let her off the hook, morally speaking. Not only was she always anxious, from schooldays, to hide her 'private and ecstatic' love from the 'authorities', but too often in mature years the 'preferences' upon which she embarked infringed the power relationships inherent in her position as head of a women's college. Even in her days at Girton, living amidst student equals, she exercised her proselytizing role as prophet with a force which had something of the emotional bully about it. She justified the intensity with which she pursued occasions for intimate conversations by the spiritual necessity of securing their souls for God. Rarely satisfied that she had sufficiently 'moved' the souls of those with whom she 'wrestled', until she had reduced them to tears, she would then comfort them by stroking their hair or similar acts of physical consolation. The advice she received from Lewis Campbell, the Professor of Greek at St. Andrews and almost twenty years her senior, that 'sisterly- kindness' and 'charity' might prove more effective than her chosen method of buttonholing each of her fellow students in their bedrooms at the end of term, seems entirely apposite. ${ }^{40}$ 
By 1916 Maynard was convinced that 'the autobiography can never see the light during my lifetime'. ${ }^{41}$ Possibly the introduction to the entire manuscript that she penned in 1925 was directed at posterity, or was intended to preface a more immediate major revision of her material. However, as the manuscript stands, the autobiography bears little continuous sense of a readership beyond herself. There are moments when she seems to be defending her reputation in front of some wider tribunal: she is, for instance, anxious to present herself as attractive to the opposite sex, recounting with considerable pride the proposal she received in 1869 from the oldest of twelve fatherless children of an Evangelical parson, ${ }^{42}$ or the intimate walks and unspoken mutual devotion she believed she had enjoyed with Lewis Campbell, with whom she felt she enjoyed far better intellectual rapport than did his wife. ${ }^{43}$ Yet in the main, as she quarried the Green Books so she relived the pains and excitements of earlier years. ${ }^{44}$ There is very little evidence of a detachment sufficient to allow for recognition and evaluation of her earlier selves. The origin of the Green Books may well have lain in an opening up of the inner self before God, but even this explanation for the autobiography's impulse is complicated. Self-exoneration and self-justification are frequently to the fore, and indeed a sense of presenting herself before the final Judgement Seat sometimes consoled her: in the final volume of her autobiography she recorded attending a Commemoration Day at Westfield College in 1922, where she was bitterly disappointed by no mention of her own foundational work being made, but reassured herself, that whatever her limitations, 'In the unsparing light of the Great Day, all will be told'. ${ }^{45}$ Such moments are amply counterbalanced by a conviction of her own ability, and indeed duty, to judge all those she encounters, and since her emotions are rarely recollected in tranquillity, she is often inclined to mingle moral evaluations with her personal likes or dislikes. 
What then do the entirety of Maynard's rambling, repetitive, but intense, autobiographical recollections offer readers today? Read as a historical source they provide valuable evidence of a particular phase in women's education, and Maynard's part in it, but this could be adequately represented in the form of extracts. Read in the wider context of nineteenth-century women's life-writing, their illusion of absolute recall, derived from her access to diaries of many years before, offer vivid vignettes, but taken over the longer run, do not provide continuous fine writing. Nor, because of the focus on her very personal appraisal of the way in which her public life made its impact on her inner being, does her objective contribution to women's higher education, attain the prominence it deserves. Her childhood, moreover, was not perhaps as exceptional as she seemed to believe. Speaking of their upbringing in a home, where at the age of twenty-three she was finally permitted to accept the oft-repeated invitation to stay with her 'worldly' godmother in St. Andrews, ${ }^{46}$ she spoke of herself and her sister Gaby as 'eagles in a hen-house'. ${ }^{47}$ Yet her account, to some extent, does a disservice to the advantages she enjoyed: judged by conservative middle-class standards her early education was unexceptionable, and she eagerly acquired Latin, as other girls often had to, from her younger brother's schooling. Although she claimed to have been deprived of the contemporary fiction which she believed would have taught her how to handle unwelcome proposals, ${ }^{48}$ the children were permitted the novels of Sir Walter Scott and she recalled being read Margaret Oliphant's Passages in the Life of Mrs. Margaret Maitland of Sunnyside (1849) by her mother ${ }^{49}$ - presumably Oliphant scraped under the radar as the biographer of the parents' hero, Edward Irving. Even considered as an account of the problems Maynard faced in wishing to reconcile her religious faith with the rationalism inherent in the study of Moral Sciences which she undertook at Cambridge, her struggle, though more intensely felt, was not that dissimilar from that encountered by many contemporary Christians. 
Rather, her autobiographical writings come into their own as a spiritual autobiography offering a very distinctive example of embodied theology. It was Maynard's recognition that the genteel confines of wealthy middle-class English society offered little by way of Christian mission to the aspiring female, beyond dutifully inhabiting the roles of daughter, wife and mother, which drove her sense that she could only achieve a meaningful life through daring to place herself outside the roles conventionally assigned to her gender. Consulting her Bible for guidance, she frequently appropriated tales of male characters to understand her own situation: deciding to return to Girton, despite her disappointment at her failure as God's prophet to secure the instant conversion of her fellow students, she recognized herself in the figures of Joshua, the young King David, Daniel, Job. ${ }^{50}$ Having no real interest in working with the poor, or aptitude for Sunday School teaching, accepting that her close friendships were all with women, and that she actively shrank from physical contact with the male sex, how could a girl with 'a hunger for love ${ }^{51}$ serve Christ?

Fortunately, as she remarked, by the 1870 s George Eliot's 'more virile type of womanhood' had entered the public consciousness and replaced the 'diffident' or 'shrewish' spinsters of Dickens's representations. ${ }^{52}$ In this light, Maynard's early artistic aspirations can be seen as a midway position between an activity acceptable to her conservative parents, and the possibility of an independent life to be pursued in London and elsewhere. The development of the single-sex college, simultaneously offering independence from family and a small, ready-made community sharing daily pursuits and recreational time, fulfilled most of Maynard's requirements. The sheer numbers of young women who emerged from Westfield College in its early years, determined to pursue missionary service either on the home front or abroad, ${ }^{53}$ provide living testimony to the fulfillment of Maynard's vision of a Higher Education attuned, rather than antagonistic, to the purposes of Religion. 
However, there is another more troublesome aspect of her embodied theology which it is difficult to ignore. Maynard yearned for her own children, to be produced without the necessity of sexual union, and, more significantly, without their hindering her mission to Higher Education. The very brief account she offers in her autobiography, relating the year 1888, suggests that her decision to adopt a child occurred at a low point in her own emotional/spiritual life. She cleared herself of the charge of a 'thwarted sex-instinct' in relation to her 'extreme devotion' to F. R. Gray, by stating that 'Ralph's' becoming 'docile \& affectionate \& sweet' had not made her happy. Wracked once again, during her Norwegian holiday that summer, with misgivings about the reality of her own conversion, and returning to England in time to be present at her father's death-bed, she told her sisters of her intention, only to find they disapproved, so she promised not to pursue adoption actively. She therefore chose to see the Salvation Army's offer of a 6-year-old girl as providential. 'I wanted brains and the child was clever...The mother-instinct is strong, and just now \& then I felt a kind of rapture of joy at having her to be all my own'. However the decision in her Introduction to her Autobiography, written only two years earlier, when she had vowed to endeavor not to read the past in the light of subsequent developments, could not survive this episode. She continued the previous sentence about the adopted Effie, 'but that could not stand out against the ingrain evil she shewed. She was an Italian, a Roman, and illegitimate, and I could not cope with her. ${ }^{54}$

1889 found Maynard not only slightly resentful of the concentrated attention the sevenyear-old child demanded of her during the vacations, when she had her with her, but telling herself that she Maynard was 'alone, alone in all the world...an orphan, unclaimed, unwanted, homeless' ${ }^{55}$ When the child succumbed to a serious attack of measles, Maynard's thoughts 
were of her plans for the child's future, 'who was either to be my successor at the College, or the support and comfort of my old age'. Effie made a swift recovery but when 'she lamented leaving me ...I explained to her about Westfield, \& how it was the will of God'. Effie's docility on this occasion persuaded, Maynard to conclude, in 1927, that it would have been better had Effie had died then rather than living until 1919 to be 'a disappointment' ${ }^{56}$ Her failure to mould Effie did not prevent her snatching at other chances of proxy parenthood. 1916 saw her zealously monitoring the life of a great-nephew whose last years of schooling in Canada she had supported. Just short of taking his bachelor's degree he came to England to enlist, and Maynard was thrilled by the thought of acquiring a 'son' among so many daughters. Her jealous fears lest the Canadian girl he spoke of might be 'shrill' or a 'mere factory girl' do not make pleasant reading. ${ }^{57}$

Maynard herself diagnosed her inner battles in Arnoldian terms as the 'immortal struggle between the Greek and the Hebrew,${ }^{58}$ but her deeper spiritual anxieties perhaps lay in possessing a Romantic desire for the Absolute, occasionally sensed by her in the natural world, that warred with the terms in which her religious upbringing had taught her to identify the Absolute with a lasting 'assurance' of being part of the Kingdom of God. The 'oceans' of writing, in which she sought to capture the essence of her prophetic mission were another version of the 'furlong' in the remotest reach of the garden at her childhood home which she had marked out for herself as a place where she hoped to find peace, but more frequently paced in a torment of frustrated desire for a world beyond its confines. ${ }^{59}$ 


\section{References}

${ }^{1}$ C. B. Firth (1949) Constance Louisa Maynard: Mistress of Westfield College: a family portrait (London: G. Allen and Unwin); J. Sondheimer (1983) Castle Adamant in Hampstead: a history of Westfield College, 1882-1982 (London: Westfield College, University of London); M. Vicinus (1985) Independent women: work and community for single women, 1850-1920 (London: Virago).

${ }^{2}$ E.g., J. Swindells (Ed.) (1995) The Uses of Autobiography. Gender \& Society: feminist perspectives on the past and present (London: Taylor \& Francis).

${ }^{3}$ Margaret R. Miles (1998), Practicing Christianity: critical perspectives for an embodied spirituality (New York: Crossroad), p. ix.

${ }^{4}$ See D.B. Hindmarsh (2005) After Christendom: evangelical conversion after Christendom: evangelical conversion narrative and its alternatives (Oxford: Oxford University Press).

${ }^{5}$ Constance Maynard, Green Book, Queen Mary, University of London Archives, PP7/1, 1866, p. 2 [hereafter cited as Green Book]; and Green Book, 1916-1919, p. 199. For digital version see $<$ http//:www.library.qmul.ac.uk/archives/digital/constance_maynard $>$. In citing these MSS I have followed Maynard's numbering on the individual pages of each volume of both the Green Books and the autobiographical chapters, rather than the numbering of the digitised pages which sometimes include two of her numbered pages.

${ }^{6}$ Green Book, 1866.

${ }^{7}$ Constance Maynard, Unpublished Autobiography, Queen Mary, University of London Archives PP7/6, Vol. 2, Chapter 4, p. 1 [hereafter referred to as Autobiography].

\footnotetext{
${ }^{8}$ Autobiography, I, 3, pp. 53-54.

${ }^{9}$ Green Book, 1866, p. 1.

${ }^{10}$ Autobiography, II, 9, pp. 241-46.

${ }^{11}$ Autobiography, II, 8, pp. 211-13.
} 
${ }^{12}$ Autobiography, II, 7, pp. 158.

${ }^{13}$ Ibid., p. 149.

${ }^{14}$ Ibid., p. 150.

${ }^{15}$ Autobiography, II, 4, pp. 61-64.

${ }^{16}$ Autobiography, I, 3, p. 45.

${ }^{17}$ Autobiography, II, 7, p. 158.

${ }^{18}$ Autobiography, II, 8, p. 232.

${ }^{19}$ Green Book, 1916-1919, pp. 274-75.

${ }^{20}$ Autobiography, III, 26, p. 788.

${ }^{21}$ Autobiography, II, 8, p. 198.

${ }^{22}$ Autobiography, II, 6, p. 131.

${ }^{23}$ Green Book, 1916-1919, pp. 16-17.

${ }^{24}$ Autobiography, III, 26, pp. 770-89.

${ }^{25}$ Green Book, 1916-1919, p. 21.

${ }^{26}$ Autobiography, 1921-1927, pp. 36-37.

${ }^{27}$ Autobiography, I, 2, pp. 28-30.

${ }^{28}$ C. Brontë (1969), Jane Eyre, ed. J Jack and M. Smith (Oxford: Clarendon Press), p.462.

${ }^{29}$ Autobiography, I, 1, pp. 1-3.

${ }^{30}$ Autobiography, VII, 49 (Draft b.), p. 128

${ }^{31}$ Autobiography, I, 1, p. 3.

${ }^{32}$ Autobiography, II, 6, pp. 104-105.

${ }^{33}$ Autobiography, II, 4, p. 60; and II, 6, p. 108.

${ }^{34}$ Autobiography, II, 4, p. 571.

${ }^{35}$ Autobiography, II, 6, p.106.

${ }^{36}$ Autobiography, II, 9, p. 241. 
${ }^{37}$ Autobiography, III, 11, p. 361.

${ }^{38}$ Matthew 6:33, quoted in $A$, III, 11, p. 372.

${ }^{39}$ Autobiography, VII, 49 (Draft b.), pp.128-134.

${ }^{40}$ Autobiography, III, 11, p. 368.

${ }^{41}$ Green Book, 1916-1919, p. 3.

${ }^{42}$ Autobiography, II, 7, pp. 173-84.

${ }^{43}$ Autobiography, II, 9, pp. 268-69.

${ }^{44}$ Green Book, 1916-1919, p. 4.

${ }^{45}$ Autobiography, VII, 1921-1927, p. 13.

${ }^{46}$ Autobiography, II, 9, p. 250.

${ }^{47}$ Autobiography, II, 7, p. 163.

${ }^{48}$ Ibid., p. 175.

${ }^{49}$ Autobiography, I, 1, p. 15.

${ }^{50}$ Autobiography, III, 11, p. 378.

${ }^{51}$ Autobiography, I, 1, p. 4.

${ }^{52}$ Autobiography, III, 11, p. 335.

53 See Angharad Eyre (2014) 'Zeal and Sacrifice: the Woman Missionary and Women's Writing, 1830-1900, Ph.D dissertation, Queen Mary, London, p. 223.

${ }^{54}$ Autobiography, VII, 52, p. 232.

${ }^{55}$ Autobiography, VII, 53, p. 244.

${ }^{56}$ Ibid., pp. 245.

${ }^{57}$ Green Book, 1916-1919, p. 8.

${ }^{58}$ Autobiography, II, 9, p. 259.

${ }^{59}$ Inter alia, Autobiography, II, 9, p. 288. 